University of Louisville

ThinkIR: The University of Louisville's Institutional Repository

Electronic Theses and Dissertations

1932

\title{
Studies in the diphenyl series III : 4,4'-dichlorotrinitrodiphenyl.
}

H. Harris Ruwe 1908-1980

University of Louisville

Follow this and additional works at: https://ir.library.louisville.edu/etd

Part of the Chemistry Commons

\section{Recommended Citation}

Ruwe, H. Harris 1908-1980, "Studies in the diphenyl series III : 4,4'-dichlorotrinitrodiphenyl." (1932). Electronic Theses and Dissertations. Paper 1903.

https://doi.org/10.18297/etd/1903

This Master's Thesis is brought to you for free and open access by ThinkIR: The University of Louisville's Institutional Repository. It has been accepted for inclusion in Electronic Theses and Dissertations by an authorized administrator of ThinkIR: The University of Louisville's Institutional Repository. This title appears here courtesy of the author, who has retained all other copyrights. For more information, please contact thinkir@louisville.edu. 


\title{
UNIVERSITY ON LOUISVILLE
}

\author{
9TUDIES IN THE DIPAEML BRRIAS III. \\ 4,4'-DIOHLOROTRIKITROD IPLENY L
}

\begin{abstract}
A Diseertation
subatted to the laoulty of the Cxaduate

Bohool of the univerelty of Loul oville

In Partial Nulfiliment of the

Roquirements for the Degree

of Maater of golenoe
\end{abstract}

Dopertmontoce Choul stry

ty

H. Harr 10 Fuwe

2932. 


\section{TABLE OF CONTENTS}

I. Introduction:

PAGE NO.

A. Objeotive.................... I

B. Historical................. 3

c. Theoretionl................ 4

II. Experimental:

A. Oxidations and Reduotions........99

B. Nitrations..................21

c. Purifloations.................29

D. Nitrogen Analysis...............33

III. Conclusions.......................

IV. Blbllography................... 35

v. Autoblography..................37 
IMTRODUCTION 


\section{OBJECTIVE}

Hitrated dlohlorodiphonyls having reposted nitrogen contente correeponding to trinltrodiohlorodiphenyl have been propared by direot nitration of 4,4"-diohlorodipheny (1). The two products secured by this nitration, one melting at $164-165^{\circ}$ and having a nitrogen oontent of $11.64-11.71$ per oent, the other welting at $143-147^{\circ}$ and haring a nitrogen content of 11.03-11.19 peroent, were thought to be 180mers. alnce the one melting at $143-147^{\circ}$ has a range of several degrees in melting point along with a nitrogen oontent ap proximately .62 per cent below that of the theoretlcal for dlohlorotrinltrodiphenyl, it was poseIble that the lower melting compound wa ldentloal -1th the higher one but $20 s 8$ pure.

The prime purpose of the work to be desoribed In this thesis was to determine the positions of the nitro-groupe in 4,41-dichlorotrinitrodiphenyl, welting polat 164-165, and to study further the lower melting compound with a view of determining whether or not 1 was truly lsongrio with the first. In addition, a study of the phyaloal and obemioal properties of both nitro-derivatives was projected in order to inozese the relatively low yleld of the higher melting compound through the applioation of such knorledge. 
It was proposed also to cheok the wethod of nitration previously referred to, as well as the analyt1cal method, whioh was more or 1088 new, in applioation to this type of nitrogen compounds. 


\section{HISTORIOAL}

The first diphenyl derivatives of the type to be studied were prepared by a reaction in which aubstituted aryl halides were treated with copper, thus coupling the benzene nuclel at the polnt ocoupled by the halogens. The ylelds obtalned by this method were very low, and in proportion, the cost was so great that only a limlted amount of researoh was oarried on. No commerclal applioat1ons were possible under such conditions. Reoently diphenyl has been made by passing benzene and steam over oracking surface such as pumlce at a hlgh temperature and pressure (2). A large jleld was obtained by this method at a relatively 10 w $008 \mathrm{t}$, and derivatives of atphongl are now made from diphenyl itself, by ualng the mell known substitution reactions. A comerolal outlet for the chloro- and nitro-derivatives was soon found in the production of stable gums, resins, and dye intermediates. Thus was opened a fleld of researoh with seemingly unlimited possiblifties. 
THEORET IOAL

on oxidation of dipheny 1 , benzolo aold is produced; therefore, on oxidation of a trindtroderivative of 4,41-diohlorodiphenyl in whioh two nitro-groups are on one ring and one nitro-group on the other a 4-chlorodinitrobenzolo aold should be produced. The reason for belleving the nitrogroups are distributed in such manner will bo read1ly understood after reading the disoussion in regard to the orientationoof the firat two n1tro-groups mentloned later in this seotion. comparison of the 4-ohloro-XY-dinltrobenzo10 ac1d, so produoed, with known 4-ohlorodinitrobenzolo aolds should be suffiolent in determining the positions of two of the nitro-groups on one ring.

It has been ahown by Erlenmeyer and Graebe that a nitro-group on a benzene ring renders that ring stable toward oxidation, whlle an amino-group makes the ring more susceptible to axidation (3). On oxidation of nitronapthalene, nitrophthal1c aold was produced, but when aminonapthalene was oxidlzed phthalio aold was produced.

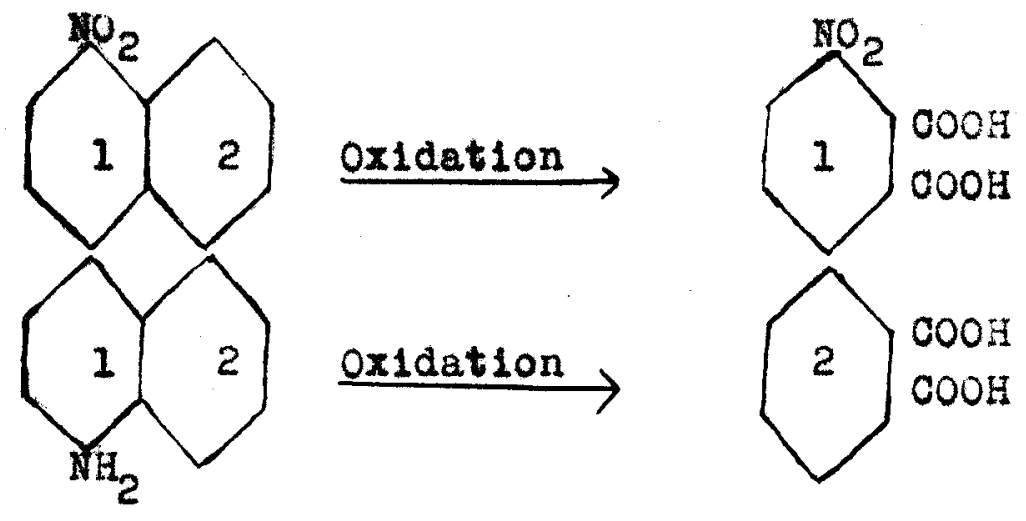


Therefore di- and trin1tro-derivatives of diphenyl in whloh there is at least one nitro-group oneeach ring, would not be expected to readily undergo oxtation. On the other hand it has been shown that 4,4'-dichlorodinitrodiphenyl, which was also prepared by direot nitration, reacts with aloohol10 ammonla and plperidine, under normal conditions, to forn 4=ohloro-4'-aminodinitrodiphenyl and 4-chloro-41-plperidinodinitrodiphenyl respectively. These reactions being typlosl of allphat1c groups, (4). It was thought that one

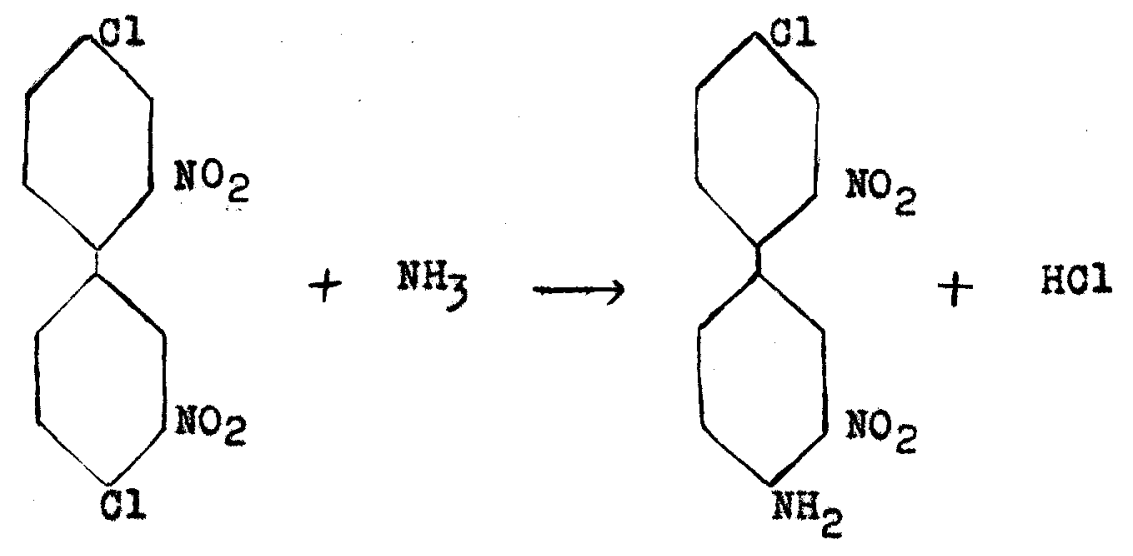



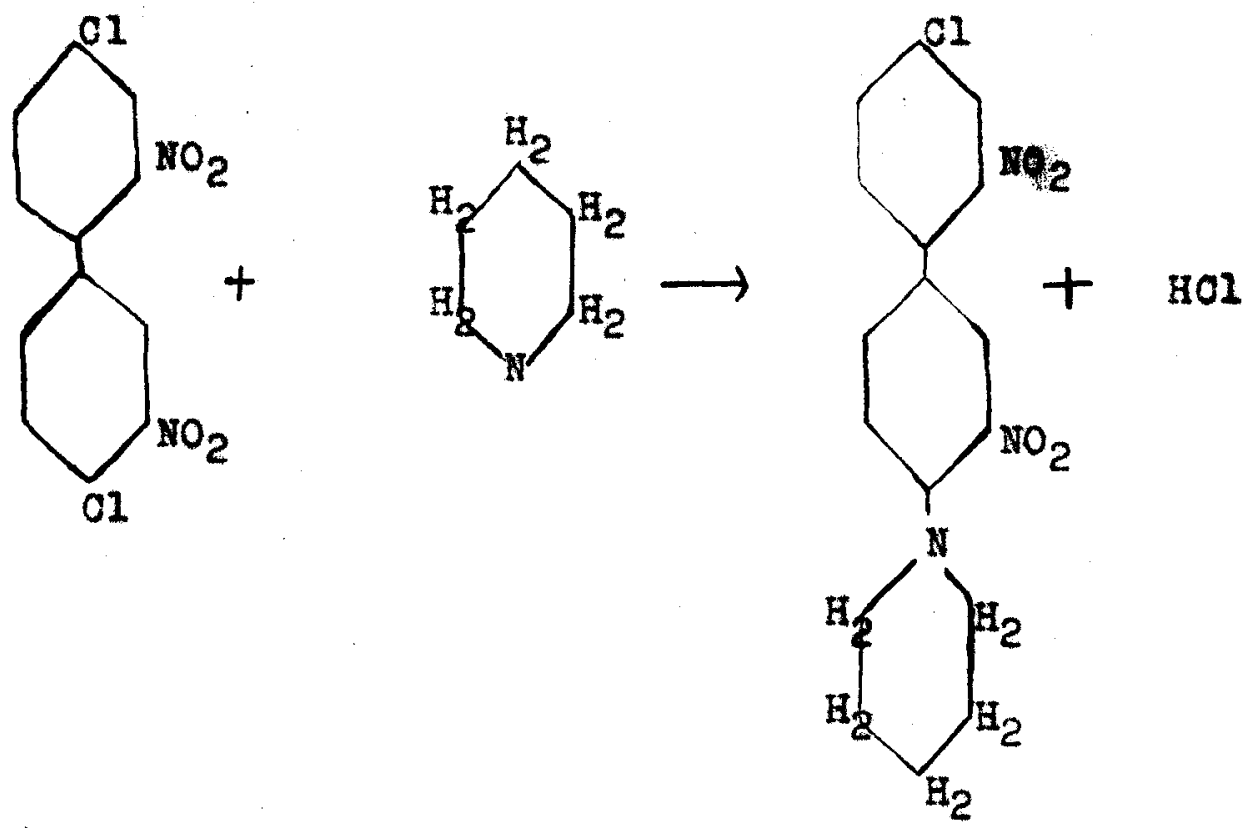

of the ringe may aot as an allphatio grouping, espeolally when oertain groups are present on the Iing. Thus it was thought that 4,4'-diohlorotrinitrodiphenyl, prepared by direot nitration, would have the same properties and possibly undergo direot oxidation. If the 4,41-dichlorotrinitroAlpheny 1 would not undergo direct oxidation, then one or more of the nitro-groupe could be reduced to the corresponding amino-groups, forming, as mentloned before, a compound whioh should be quite susoeptible to oxidation. Howerer, the location of the position of the third nitro-group necessitates an entirely different and more complloated procedure.

Fuxther nitration of a 4,4'-dichlorodinitrodiphenyl, prepared by direot n1tration of 4,41diohlorodiphenyl, might reasonably be expeoted to gite a trinitro-body corregponding to one of those under oonsideration. This, if sucoessful, would 
f1x the positions of two of the nitro-groups, provided these positions were knom prior to the introduction of the third. Suoh a dinitrodichlorobody was avallable in 4,4'-dichloro-2,3'-dinitrodiphenyl, so this moans of attaok was used simultaneously with the one first mentioned.

In connection with the positions of the nitrogroup in the above mentioned compound, a controversy has arisen whioh it is neossary to disouss briefly. Direot nitration of 4,4'-dibromodipheny 1 by Lellman's Method produces a mononitro-compound, melting at $124^{\circ}$, whioh is identioal with 4,41-dibromo-2-n1trodiphenyl prepared with 2-nitro-benz1whe (5). On further nitration of Lellman' mononitro-compound a dinitro-compound was formed, which corresponded with the dinitro-derivative of 4,41dibromodiphenyl prepared by Schultz and on reductIon a diamine, melting at $89^{\circ}$, was formed whlch was Identioal with the diamine prepared by sohultz (6). The latter diamine would not undergo condensetion of the type to be expected of a symmetrioal diamine. This peoullarity led Dennet and Turner to belleve that the dinitro-derivative was unsymmetrical, (7), and on further study it was found that the dinitro-compound depressed the melting point of the 4,41-dibromo-2,2'-dinitrodiphenyl prepared from 2,5-dibromonitrobenzene ( 8 ). The unsymmetrioal dinitro-compound reacted vigorously with pip- 
eridine to give a bromopiperidino-nitrodiphenyl, $14,41-d 1$ bromo-2-n1trodiphenyl and 4,41-d1bromo2,2'-dinitrodiphenyl were not affeoted by piperidine, and it is therefore clear that the above p1peridino-derivative is 4,41-dibromo-2,31-dinitrodipheny 1 , and that the original dinftro-compound is the 2,3'-derivative."

The dinitro-derivative of 4,41-dichlorodiphenyl, melting at $140^{\circ}$, described by sohnidt andatat Schulz was similarly found to be 4,41-diohloro-2,3'dinitrodiphenyl (9).

Hodgson also prepered a dinitro-derivative of 4,4'-dlohlorodiphenyl from $3,3 \cdot(2,3$ '?)-dinltroben-zld adine which was 1dentioal with the direotly nitrated 4,4'-diobloro-dinitrodiphenyl (10). On treating the dinitro-compound with an excess of alcohol10 ammonia be found that only one of the chlorine atoms was readily diaplaced by amonla. Therefore, if the alnitro-derivative of benzldine was either of the two possible isomers mentioned, it must have been the unsymmetrical one, (11), as only one chlorine atom reacted with anmonia to form 4-chloro-4'-aminodini trodi pheny 1 . 
EXPZRIIENAI

$\checkmark$ 
EXPERIMENTS

OXIDATION OF 4,41-DIOHLOROTRIHITRODIPHEIYL

A mixture composed of 3.5 grams $(.01 \mathrm{~mol})$ of 4,41-d10hlorotrinitrodipheny 1 , melting at $164-165^{\circ}$, 4.7 grame (.03 mol) of potaselum permanganate, and 54 grams (3.0 mol) of water was placed in a 200 c.0. tlask fitted with atirrer and a reflux condenser. The mixture was heated on a water-bath with continuou stirring unt1l the permangenate color dioappeared, which took 3.5 hours (12).

The mixture was filtered, and the manganese dioxide that remalned a resldue was disoarded. The flitrate was olarifled by treating with animal oharcoal, acidified with hydroobloric acid and extracted with ether. After the ether had evaporam ted a few colorless orystals remained, but the quant1ty was insufficient for analyoli.

This method of oxidation was repeated four timea, each time the oonditions being varied, as shown in Table 1, but none of the extraotions contained organic matter.

Since these regults were negative, it seemed neoessary that one or more of the nitro-groups would have to be reduoed before the compound would undergo oxidation, as was previously mentloned in the theoretical disoussion. 
OXIDATION OF 4,41-DICHLOROTRINITRODIPHENYL

Run Subatances used Grams Mols Time Temp. Yleld

1 4,41-dionloro-

trinttrodipheny 1

$\mathrm{KunO} 4$

$\mathrm{H}_{2} \mathrm{O}$

$\begin{array}{ll}3.5 & 0.01 \\ 4.74 & 0.03\end{array}$

54. 3. $3.5 \mathrm{hr} .1000 .00 \mathrm{gr}$.

2 4,4'-dionloro-

trinitrodipheny 1

$\mathrm{KBinO}_{4}$

$\mathrm{H}_{2} \mathrm{O}$

$\begin{array}{ll}7.1 & 0.02 \\ 9.48 & 0.06\end{array}$

54. 3. $4.0 \mathrm{hr}, 100^{\circ} .00 \mathrm{gr}$

3 4,41-dionioro-

trint trodipheny 1

$\mathrm{KunO}_{4}$

$\mathrm{H}_{2} \mathrm{O}$

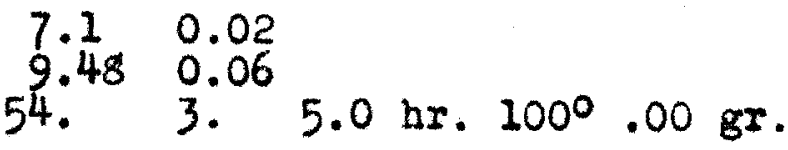

4 4,41-dichloro-

trinitrodipheny 1 10. 0.028

$\mathrm{KMnO}_{4}$

$\mathrm{H}_{2} \mathrm{BO}_{4}$

$4.74 \quad 0.03$

$4.2 \quad 0.045$

$11.50 .62 .0 \mathrm{hr} .1000 .00 \mathrm{gr}$.

5 4,41-d1onloro-

trindtrod1pheny 110

$\mathrm{KMnO}_{4}$

$\mathrm{H}_{2} \mathrm{SO}_{4}$

9.5
8.4
4.6

0.028

0.06

0.09

$0.252 .0 \mathrm{hr} .1000 .00 \mathrm{gr}$. 
ATTEUPTED REDUOTION OF ONE NITRO-GROUP

OF 4,4'-DICELOROTRINITRODIPHENTL.

The following method wes used in an attempt to re-duoe only one nitro-group:- a mixture made up of 3.5 grams $(.01 \mathrm{~mol})$ of 4,41 -dioholrotrinitrodiphenyl, 42.5 grams (.9 mol) of alcohol, and 7 grame (.2 mol) of amonium hydroxide was plaoed In a flakk and heated. Hydrogen aulfide was then added unt12 the welght had inoreased 3 grame $(.085$ mol). Then 100 grams $(5.55$ mole $)$ of water was addod and the solution neutrallzed with sodium hydrox1d. to preolpitate the amine (13).

The preoipitate, a mixture oomposed of a reddish brow powder and a small quantity of yellow cryotale, was dried and washed with aootone. After the acetone had evaporated, a mixture of brown and yellow orystals remalned. The produot melted at $122-135^{\circ}$.

There is no doubt that a reaction had taken place in this reduction, as the solutions obtalned on dissolving the monoamine in varlous solvents were highly colored while the solutions made of the same solvents and trinitro oompound were clear or elightly yellow. Due to the similarity of 4,4'-dichlorodin1troaminodiphenyl and 4,4'-diohlorotrinitrodiphenyl, it wa imposatble to obtain the amine in a pure state. A reduotion by the use of $\operatorname{tn}$ and hydroohlorio ac1d was then attempted, as auch a reaction should produce a triamine hav- 
ing properties oufflolently different from the mother substance to make a complete separation possible. 
ATTEMPTED PREPARATION OF 4,4*-DICHLORTRIAMINPHEMTL

A m1xture of 3.5 grams $(.03 \mathrm{~mol})$ of $\mathrm{tin}$, 2.16 grams (.12 mol) of rater, and $10 \mathrm{grams}(.028$ mo1) of 44,4'-diohlorotrinitrodiphenyl was placed in a 200 c.0. Plesk fitted with a reflux condenser and stirrex. Then $2.16 \mathrm{grams}(.06 \mathrm{~mol})$ of hydrochlorio aold were added, and the contents were heated to $70^{\circ}$ with oonstant stirting for 1.5 hours. The solution was then flitered, and the floresoent flltrate was neutrallzed with sodium hydrox1d. and saturated with sodium ohloride. On atand1ng, 2.5 grams of a dark brom resinous product preoipitated out.

This method of reduction was repeated several times, belag modifled each time as shom in table II, in an attempt to increase the yleld of 4,41-diohlorotriaminodiphenyl.

In mun number two the reduotion was carried out the same as in the first, but was refluxed for 1 hour inetead of 1.5 hours. On purification a larger quantity of unohanged tin and 4,48-dioblorotrinitrodiphenyl remained in the residue.

In run number three the entire residue was dried; washed with acotone, and diluted with hydroohlorio aold to precipitate out the trinitro-oompound. The solution was then filtered, and the f1ltrate was evaporated to dryness on a steam-bath. In run number four the solution was filtered, 
and the filtrate was evaporated to dryness on a steam-bath and vaouum distilled. The dist1llate solidified, forming a yellow powder which melted at $125-133.5^{\circ}$. Th1s produot was not eas1ly condensed, mach of it being carried over into the vacuum gump.

Runs numbers five and six were purifled the same as run number three.

Runs numbers seren and elght were purifled as follows:- the entire solution was diluted to 5000.0 . and hydrogen sulfide was added until the tin had completely precipitated. The solution was then filtered and the filtrate dried on a steambath. There was a small quantity of 1mpurities in the amine, most of which was thought to be Iree oulphur.

Although the method used in the purifioation of runs three, five, and six did not produce yields which were as high as those produced by the method used in the last two runa, the products contalned less impurities. It was not possible to purify the compound sufflolently for analysis and complete Identifioation, but the general appearance and properties of the product were such that it was belleved that the trinitro-oompound had been at least partly reduced. Bren partial reduotion would have been suffiolent for the purpose of rendering one ring more eusoeptible to oxidation so the next group of experiments were attempts to 
oxid1ze the reduced product to ohloronttroben2010 ac1ds. 
ATTEMPTED PRRPARATION OF 4,4'-DIOHLOROTRIAMIK

\section{DIFHENYL}

Run Substances used Grams vols Time Temp Y101d

1 4,41-diohloro-

$\begin{array}{lllll}\text { trinitrodipheny } 1 & 10 . & 0.028 & & \\ \text { Sn } & 3.5 & 0.03 & & \\ \text { Hol } & 2.16 & 0.06 & & \\ \mathrm{H}_{2} \mathrm{O} & 2.16 & 0.12 & 1.5 \mathrm{hr} .75^{\circ} & 2.5 \mathrm{gr} .\end{array}$

2 4,41-diobloro-

trinltrodipheny 1 10. 0.028

Sn

$\mathrm{HCl}$

$\mathrm{H}_{2} \mathrm{O}$

$\begin{array}{ll}3.5 & 0.03 \\ 2.16 & 0.06\end{array}$

$2.160 .12 \quad 1.0 \mathrm{hr} .75^{\circ} 2.3 \mathrm{gr}$.

3 4,41-d1ohloro-

trinitrodiphenyl

Sn

HOI

$\mathrm{CH}_{3} \mathrm{COOH}$

$\mathrm{H}_{2} \mathrm{O}$

5.5
3.16

1.8

20 .
0.014

0.03

0.06

0.03

1.9

$2.0 \mathrm{hr} .100^{\circ} 2.6 \mathrm{gx}$.

4 4,41-diohoro-

trinitrodipheny 1

Sn

HOI

$\mathrm{H}_{2} \mathrm{O}$

7

3.6

0.06

20. $\quad 1.9 \quad 2.0 \mathrm{hr} .100^{\circ} .7 \mathrm{gr}$.

0.014

0.06

0.016

5 4,4'-diohloro-

trinitrodiphenyl

Sn

HCl

$\mathrm{H}_{2} \mathrm{O}$

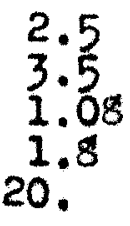

$$
1.0 \mathrm{hr} .75^{\circ} 2.3 \mathrm{gr}
$$

6 4,41-d10hloro-

trinitrodipheny 1

sn

HOI

$\mathrm{CH}_{3} \mathrm{OOOH}$

$2 \cdot 5$
10.5
25.92
20.

0.0069

0.03

0.03

0.03

$1.95 .0 \mathrm{hr} .30^{\circ} 1.6 \mathrm{gr}$.

7 4,4'-dichloro-

trin1 trodi pheny 1

Sn

HCl

$\mathrm{CH}_{3} \mathrm{OOOH}$

2.5
10.5

25.92

0.089

0.09

0.72

0.35

$5.0 \mathrm{hr} .25^{\circ} 1.8 \mathrm{gr}$.

8 4,41-dichloro-

trinitrodipheny 1

sn

$\mathrm{HCl}$

$\mathrm{OH}_{3} \mathrm{OOOB}$

0.089

0.09

0.72

0.33

$9.0 \mathrm{hr} .25^{\circ} 1.82 \mathrm{gr}$. 
OXIDATION OF REDUCED

4,41-D ICHLOROTRIN ITROD IPHEWYL

A mixture of 3.29 grams $(.01 \mathrm{~mol})$ of a product belleved to be chlorotriaminodipheny $1,1.58$ grams (.01 mol) of potassium permanganate, 3.5 grams (.035 mol) of sulphurio acid, and 10 grams (.55 mol) of water was placed in a 2000.0 . flask fitted with a stirrer and a reflux condeneer, and heated on a water-bath with constant atirring unt11 the permanganate color dlsappeared.

The mixture was filtered, and the manganese dioxide that renalned as a residue was discarded. The filtrate was olarifled by treating with animal charooal, acldifled with hydrochloric acid, and extracted with ether. After the other had evaporated a small quantlty of brown powder resained, which was then analyzed, and proved to be mostly inorgan10 matter.

This method was used in the following oxidatIon, and, as the reagents and quantities are given in table III,only the results of the purifloations will be mentioned here.

In run number two, Ilgroln, benzene, and obloroform were used to extraction solvents. The 11groln and benzene extraotions were completely negative, but on evaporation of the chloroform a very small quantity of brown reains remalned. The resIns were soluble in conoentrated hydrochlorio acid, but insoluble in both neutral and alkaline solut- 
10ns. It was therefore thought to be the original triamine-compound.

In run number three, since onromic acid was used as the oxidizing agent instead of potassium permanganate, an entirely new method of purification was necessitated. The solution was made alkaline with ammonlum hydroxide, and the chromium hydroxide was flitered off. The red filtrate was divided into two parts: the f1rat was acidified Wth hydrochlorio acid and extracted with ether. The ether extraotion was negative. The second portion was saturated with sodium obloride, and a brown precipltate was throun out of solution. on investigation the brown prooipltate was be11 eved to be the original triamine.

In run number four the solution was again neutrallzed with emmonlum hydroxide, but, instead of a green preolpltate of chromium hydroxide being formed, a small quantity of brom substance preolpltated. The brown substance was soluble in oonoentrated hydrochlorio acid, forming a red solution, and slightly soluble in a neutral solution. It was therefore thought to be the original amine. The fittrate was again acidifled, anaken with ben$z$ ene, and the two layers separated. After the benzene had evaporated nothing remained. The aqueous layer was then neutrallzed with sodlum aydroxide, and steam distilled, but without success. 
In this group of experiments it was shown that the reduction was not sufflolent to render one ring susceptible to oxidation. It was possible that the oxidations attempted merely changed any amino-group baok to the original nitro-group. 
ATTEMPTED OXIDATION OF PRODUCT IDENTIFIED AG $4,41-D T C H L O R O T R I A M$ INOD IPHENYL

Run Substances used Grams Mols Time Temp. Yleld

1 4,4t-dicholrotr1aminodl pbeny 1 $\mathrm{KMnO}_{4}$ $\mathrm{H}_{2} \mathrm{SO}_{4}$ $\mathrm{H}_{2}^{2} \mathrm{O}$

$$
\begin{aligned}
& 3.29 \\
& 1.58 \\
& 3.5 \\
& 10.5
\end{aligned}
$$$$
0.01
$$$$
0.01
$$$$
0.035
$$$$
0.55
$$

2 4,41-d10hlorotr1aminodi pheny 1 $\mathrm{KMnO}_{4}$ $\mathrm{H}_{2} \mathrm{SO}_{4}$

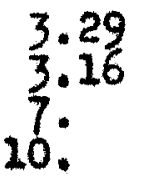

0.01 0.02 0707 $0.552 .5 \mathrm{hr} .85^{\circ} \quad .00$

3 4,41-d10hlorotr1aminod I pheny 1 $\mathrm{CrO}_{3}$ $\mathrm{OH}_{3} \mathrm{COOH}$

$$
\begin{aligned}
& 1.65 \\
& 1.8
\end{aligned}
$$
60 .

$$
\begin{aligned}
& 0.005 \\
& 0.018
\end{aligned}
$$
i. $2.5 \mathrm{hr} .90^{\circ} \quad .00$

4 4,4'-dichlorotr1aninod 1 pheny 1 $\mathrm{CrO}_{3}$ $\mathrm{OH}_{3} \mathrm{OOOH}$ 2.45 3.6 120. 0.0075
0.036 2. $1.5 \mathrm{hr} .90^{\circ} \quad .00$ 
PREPARATION OF 4,4'-D IOHLORO-2,3'-DINITRODI PHENY L

A mixture of 1.96 grams (.02 mol) of concentrated oulphurio aold, speo1110 gravtty 1.84, and 7.56 grams (.12 mo1) of red fuming nitrio eo1d, speo1flo gravityl.45, placed in a 2000.0. Plagk and 0001 ed $0^{\circ}$. Then $14.05 \mathrm{grams}(.0606 \mathrm{~mol})$ of 4,41-dlohlorodiphenyl were slowly added. When the addition was completed the contents were heated on a water-bath at $85-90^{\circ}$ with constent stirring for 2 houxs (14).

The product was washed with water, dried, and divided into two portions. The firgt was recrystalized from ether. The f1rst fraotion to crystallze melted at $127-130^{\circ}$, whlle the second fraotion melted at $76-80^{\circ}$. The second portion was reory otallzed from benzene. The f1ret fraction to crystallze, a white powder, melted at 90-1150, wh1le the second fraotion, a pale yellow powder, melted at $85-87^{\circ}$. The eraction melting at $90-115^{\circ}$ was further purified by the use of benzene, and a new product melting at $131-133^{\circ}$ was obtained.

A $50 \%$ mixture of 4,4'-diohloro-2,3'-dinttrod1pheny 1 , melting at $136^{\circ}$, and the produot melting at $131-133^{\circ}$ inoreased the melting point of the latter to $132.5-134^{\circ}$.

The 4,4'-dichloro-2,3'-dinttrodiphenyl, melting at $136^{\circ}$, was a commerolal product, whioh had been purifled by vacuum distiliation; but on further 
purlfication by recrystallization from glacial acet10 aold, its melting point has been brought up to 140 . The nitrogen oontent of the dinitro-compound molting at $136^{\circ}$ was ohecked by the Kjedahl mothod and was found to be $3.7 \%$, whlle the theoretical is $8.9 \%$.

This mothod of nitration was also used for the following preparations, the modifloations in quant1t1es and oonditions being given in table IV:

In run number two, the produot was also divided into two portions. The flrst was reorystallized from glaolalaoet1o actd. The flrat fraction to orystal11 ze melted at 86-920, while the seoond fraction melted at $85-96^{\circ}$. The seoond portion was reorystal11zed frow aloohol. The first Iraotion to orystal11 ze melted at $97-101^{\circ}$, while the second fraction melted at $94-97^{\circ}$.

In run number three, the vibration of the stirrer cracked the condenser two hours after the run was atarted, and water ren down into the llask. There was an extreme heat produced by the reaction of the water and the fuming acids, but the heat did not seom to have had any effeot on the reaotion products as w111 be seen later.

The product was recrystallized from alcohol. The flrat eraction to crystallize melted at $126-135^{\circ}$ while the second fraction melted at $95-108^{\circ}$.

A $50 \%$ mixture of 4,4'-dichloro-2,3'-dinitrod1phenyl and the product melting at $126-135^{\circ}$. Inoreased 
the melting point of the latter to $128-134^{\circ}$.

The latter nitrations proved oufflolent insofer as only one dinltro-compound was produced, and the melting polat of the silghtly impure dinitro-oompound wes not depressed but raised when mixed with a more pure sample of 4,4'-d1chloro-2,3'-dinitrod1phenyl. Thlo oompound was prepared for further n1tration in an attempt to aecure produots 1dentioal to those formed by uninterrupted nitration of 4,4 : d10hlorodiphenyl, the nextgroup of experiments belng along that IIne.

IV

PREPARATION OF 4,4'-DICHLORO-2,3'-DIUITRODIPGENYL

Run Subetanoes used Grams Kols Time Temp. Yield*

1 4,41-dichloro$\begin{array}{lrlll}\text { dipheny } & 14.05 & 0.0608 & & \\ \mathrm{H}_{2} \mathrm{SO}_{4} & 14.96 & 0.02 & & \\ \mathrm{HHO}_{3} & 7.56 & 0.12 & 2 \mathrm{hr} .85-90^{\circ} & 9.6 \mathrm{gr}\end{array}$

2 4,41-diohlorodipheny 1 $\mathrm{H}_{2} \mathrm{SO}_{4}$ $\mathrm{HHO}_{3}$ $13.4 \quad 0.0567$

1.960 .02

$7.560 .12 \quad 2.5 \mathrm{hr} .75-35^{\circ} \quad 9.3 \mathrm{gr}$

3 4,41-diohlorodipheny 1 $\mathrm{H}_{2} \mathrm{SO}_{4}$ $\mathrm{HiO}_{3}$ $\begin{array}{cl}66.9 & 0.299 \\ 9.8 & 0.1 \\ 37.8 & 0.6\end{array}$ $3 \mathrm{hr} .50-60^{\circ} 54.0 \mathrm{gr}$

- The yteld in this table is the total yield of all fractions melting above $125^{\circ}$. 
NITRATION OF 4,4'-DIORLORO-2,31-DINITRODIPHENYL

A mixture composed of 36.8 grams $(.375$ mol) of 20-30\% fuming oulphur10 aoid and $40 \operatorname{grams}(.635 \mathrm{~mol})$ of red fuming nitric aoid, speoiflo gravity 1.45 , were poured into a 5000.0 . Hlask and oooled to $0^{\circ}$. Then14.05 gram $(.045 \mathrm{~mol})$ of 4,41-d10hloro-2,31-d1n1trodiphenyl were slowly added. Then the addition was completed the contents were heated on a waterbath at $50-60^{\circ}$ with conetant stirring for three hourg.

The entire mixture was separated into two distinet portione by filtering the aold solution through glass wool. The filtrate was then poured over crapled 1ce, and a white preolpitate deposited, which was washed unt1l free from ac1d. Tho white preolpltate was then recrystallized from glaclal aot10 aold and dried on a suotion filter. The product melted at $156-158^{\circ}$.

The pale yellow crystalline residue retalned by the glass wool was washed unt1l free from acld and reorystallized from glacial acetic acid. The first Iraotion to crystal11ze melted at $145-152^{\circ}$, wh1le the second fraotion melted at $113-120^{\circ}$.

A $50 \%$ mixture of the product melting at 156$158^{\circ}$ and the 4,4'-diohlorotrinitrodipheny 1 , melting at $164-165^{\circ}$, prepared by a Rebernak, melted at 123 . $129^{\circ}$.

This method of nitration was also used for the following nitrations, modifloations in oonditions beIng given in table $V:$ in run number two only the acld 
soluble portion was further purifled, as the reaIdue was highly contaminated with rubber from the stopper on the llask. It was flrst recrystallized from glaolal acetio aold and dried on a suction f1lter. The white crystali ine product melted at 158$162.5^{\circ}$, and, on further purifloation by reoryatal11zation from alcohol, the melting point was raised to $162-164^{\circ}$.

A $50 \%$ mixture of the product melting at 158163. $5^{\circ}$, and the 4,4'-dichlorotrinitrodipheny 1 meltIng at $164-165^{\circ}$, previously mentloned, melted at $139-145^{\circ}$.

In run number three the aoid soluble portion was reorystallized from glaclal aotio aold. The flrst fraotion to crystall1ze melted at 161-1680, wh1le the second fraction melted at 153-162\%. The fraction melting at $153-162^{\circ}$ was raouum distilled and a product melting at $158-163^{\circ}$ wa obtalned. The fraction melting at $161-163^{\circ}$ was again orygtallized from glacial acotio aold, and the melting point was ralsed to $163.5-163.25^{\circ}$.

A $50 \%$ mixture of the produot, melting at 163.5$165.25^{\circ}$, and the 4,4'-dichlorotrinitrodipheny 1 meltIng at $164-165^{\circ}$, melted at $163-164.5^{\circ}$. Thus it was beliered that the nitro-compound were identical. The depression in the mixed melting polnts of the producta obtained in the two preceding runs and 4,41-dichlorotrinitrodipheny 1 , melting point 1641650, way have been due to insuffiolent purifica- 
t1on. The reason for belleving the products of the two preceding rung were impure is shown by comparing the melting points of those products with the melting point of the product obtained from this run. In run number four the aold soluble product was recryatallized from glacial acetic aold. The more insoluble fraotion melted at $117-135^{\circ}$.

The residue was also purified by the use of glaolal aootio acid and two fractions mere obtained, one melting at $124-136^{\circ}$ and the other melting at 126$140^{\circ}$.

In run number 1170 the f11trate was again recrystallized from glacial acetio acld. The firat fraotion to crystallize melted at $156-160.5^{\circ}$, while the second fraction melted at $158-162^{\circ}$.

The residue, melted at $125-136^{\circ}$, after being reorygtallized from glaclal acetic acid.

A $50 \%$ mixture of the product, melting at 159163.5 , and the nitrated 4,4'-diohlorodiphenyl, meltIng at $164-165^{\circ}$, melted at $160-162^{\circ}$.

In run number six the produots were again reorystallized from glaolal acetio acid, and the fraotion having the blghest melting polnt melted at $152-158^{\circ}$.

A $50 \%$ mixture of the latter product and the nitrated 4,4'-dichlorodipheny 1, melting point 164-165\%, melted at $159-161.5^{\circ}$.

The results of the mixed melting points, mentioned In conneotion with the nitrations of 4,41-dichloro-2,3'-dinitrodiphenyl, were sufficient indication 
that the two compounds were 1dentloal. The fact that furtber nitration of 4,4'-diobloro-2,3'-dinitrodiphenyl glelded a compound identical with a 4,4t-diohlorotrinitrodipheny 1 , melting at $164-165^{\circ}$, showed that two of the three nitro-froups belleved present were in the 2,3'-positions. 
WITRATION OF 4,41-DIOHLORO-2,3'-DINITRODIPHENYL

Run Substanoes used Grams Yole Time Temp. Yield *

1 4,4'-dichloro-

2,3'-dinitrodipheny 1 $\mathrm{H}_{2} \mathrm{SO}_{4}$ $\mathrm{HTrO}_{3}$ 14.080 .045 36.80 .375 $40.0 .6353 \mathrm{hr} .50-60^{\circ} 7 \mathrm{gr}$

2 4,41-d10hloro2,3'-dinitrodiphenyl $\mathrm{H}_{2} \mathrm{SO}_{4}$ $\mathrm{HRO}_{3}$

14.080 .045 36.80 .375 $40 . \quad 0.635$ $5 \mathrm{hr} .50-600$ $9.7 \mathrm{gx}$

3 4,41-diohloro2,31-dinitrodiphenyl $\mathrm{H}_{2} \mathrm{SO}_{4}$ $\mathrm{HiO}_{3}$ 14.080 .045 $36.8 \quad 0.375$ 40. $\quad 0.6353 .5 \mathrm{hr} .50-60^{\circ} 8.8 \mathrm{gr}$

4 4,41-d1ohloro2,3'-dinitrodipheny 1 $\mathrm{H}_{2} \mathrm{SO}_{4}$ $\mathrm{HNO}_{3}$ $14.08 \quad 0.045$ $\begin{array}{lll}36.8 & 0.375\end{array}$ 40. $0.6354 \mathrm{hr} .50-60^{\circ} 7.5 \mathrm{gr}$

5 4,41-dichloro2,31-dinitrodipheny 1 $\mathrm{H}_{2} \mathrm{SO}_{4}$ $\mathrm{HHO}_{3}$ $24.08 \quad 0.045$ $\begin{array}{ll}46.8 & 0.375\end{array}$ 40. 0.635 $3 \mathrm{hr} .50-60^{\circ} \quad 8.9 \mathrm{gr}$

6 4,41-dichloro2,3'-dinitrodipheny 1 $\mathrm{H}_{2} \mathrm{SO}_{4}$ $\mathrm{HIO}_{3}$ $\begin{array}{ll}14.08 & 0.045\end{array}$ $36.8 \quad 0.045$ 40. $0.6353 \mathrm{hr} .50-60^{\circ}$ $9.1 \mathrm{gx}$

- The yleld is in terms of total yleld of fractions melting above $140^{\circ}$. 
PURIFIOATION OF 4,41-DOHLOROTRINITRODIPHENYL MELTING POINT $143-147^{\circ}$

Further purification of 4,41-dichlorotrinitrodlphenyl, melting polnt $143-147^{\circ}$, was attempted by reorystallizing the product from variou organic solvents and by racuum diatiliation. None of the products obtalned by these methods of purifloation showed any aporeclable ohange in melting point, so the following method was attempted:- to a mixture of 10.8 grams (.11 mol) of conoentrated sulphurio a.1d, spec1f10 gravity 1.84 , and 17.2 grams $(.27$ mol) of red fuming nitrio ao1d, specifio gravity $1.45,3$ gram (.0084 mol) of 4,41-d10hlorotrinttrodlpheny 1, melting polnt $144-145^{\circ}$, were slowly added. The contents were heated on a water-bath for 2 hours.

The mixture wag then filtered through a mat of glase wool. The filtrate was poured over cracked 100, and a white orystalline product deposited. The preolpitate was wash until eree from acld and dried in a vaouum desicoator. The product melted at $146-149^{\circ}$. The residue that remained on the glass wool was also washed and dried. It melted at $145-147^{\circ}$.

In the aecond purification a mixture of 7.36 gram (.075 mol) of conoentrated sulphuric acid, speciflo gravity $1.84,7.2$ grams $(.074 \mathrm{~mol})$ of 20$30 \%$ fuming aulphurlo acid, 21.6 grams (.184 mol) 
of fuming nitric ac1d, opeolflo gravity 1.39 , and 11 grams (.18 mol) of red fuming nitrio acid, speo1110 gravity 1.45, were poured into a 200 0.0. Ilatk and cooled to $0^{\circ}$. Then $5 \mathrm{grams}(.0139 \mathrm{~mol})$ of 4,4'dichlorotrinitrodiphenyl, melting point 145-147\%, were elowly added. When the addition was completed the contents were heated on a water-bath for 2.5 hours.

The mixture mas then filtered through glass wool. The f11trate was poured over oracked 100 and a wite crystalline aubstance deposited. The proolpltate was washed until free from acid and dried In a racuum desicoator. It melted at $146-151^{\circ}$. The residue that remained on the glass wool was also washed and dried. It was further purifled by recrystallization from glactal aoetic acid and dried on a suction f11ter. It melted at 145-1480. The acld solution used in this puriflcation was made on such basls that it would not exceed the normality of the spent acld solution obtalned from the nitration of 4,41-diohlorodiphenyl by $A$. Rebernak's motllod, whioh was 21-26 normal. As the aoldity of the latter solution wo approximately 25 normal it wes bellered that the purifloation was due to the difference in solublilty of the nitrated bodles and further nitration had not taken place. 
PURIFIOATION AND BURTHER NITRATION OF DIOHLOROTRINITRODIPHENY, MELTING POINT 145-147\%.

To a mixture of 110.4 grame (1.125 mola) of 20-30\% fuming oulphuric aold and 120 grams (1.905 mols) of rod fuming nitrlo acld, opeolflo gravity $1.45,10$ grams (.028 mol) of 4,41-dichlorotrinitrodipheny 1, melting point $145-147^{\circ}$, were slowly add ad. The oontenta were hoated on a water-bath for two hours.

The mixture was then filtered through glase wool. The filtrate was poured over craoked 100 and a wite oryetalline substance deposited. The preclpitate was wahed unt1l free from aold, dried and recrystallized from glaolal acetio ao1d. It was again washed and dried in a racuum dealccator. The produot melted at $160.5-164^{\circ}$. The residue that remained on the glasa wool was washed unt1I free from ao1d, dried, and recryatalized from glaolal acet10 acid. The orystals were very pale ye110w and meltod at $145.5-148^{\circ}$.

A $50 \%$ mixture of the fraction, melting at 160.5-164', and 4,4'-d1ohlorotrin1trodiphenyl, melting point $164-165^{\circ}$, melted at $161-164^{\circ}$. This molting point indioated that the 4,41-diohlorotrinitrodiphengl, melting point $145-147^{\circ}$, was not an 1eomer of the trinitro-oompound, melting at 164 $165^{\circ}$, but an impure fraotion of the latter. 
PURIFICATION \& MTRATION OF NITRATED 4,4:-DICHLORO-2, $3^{\prime}$-DINITRODIPHENYL, MELTING POINT

\section{$110-126^{\circ}$}

A mixture of 110.4 gram (1.125 mols) of 20$30 \%$ fuming aulphurio ac1d and 120 grams (1.905 mols) of red fuming nitric acid, spooiflo gravity 1.45 , was oooled to 00 . Then $10 \mathrm{grams}(.028 \mathrm{mols})$ of $\mathrm{n} 1-$ trated 4,4'-dichloro-2,3'-dinltrodtphenyl were slowIy added. After the addition was completed the oontents were heated on a water-bath at $60-70^{\circ}$ for three houss.

The nixture was then 11ltered through glass wool. The filtrate was poured over cracked lce and a white orystalline substance deposited, whioh was washed until free from soid and dried in a vacuum deslocator. The product melted at 164.5168 . The residue, remalning on the glass wool, was whed until free from acid, and dried on a suotion pliter. The dry realdue was reorystalllzed from glaoial acetio aold and two fractions were obtained. The firat to oryatalilze melted at $150.5-154^{\circ}$, wh1le the second melted at 144$147^{\circ}$.

Thlo run was made to confirm the bellef that only one trinltro-oompound is produced on direot nitration. 
As the nitrogen analysie of 4,41-diohlorotrinitrodiphenyl was made by the use of the modified kjedahl-cunning method, whioh was more or less new In its application to this type of compound, it was checked by the analysis of known compounds (15).

A .5 to 1. gram sample of nitro-compound was plaoed in a Kjodabl flask. To the sample were added 300.0 . of conoentrated sulphurio acid, 1 gram of salloylie ac1d, and 5 grams of codlum tholsulphate. The contents were then heated until oulphur trioxide fumes ceased to evolve. Then 2 grams of copper sulphate and 5 grame of potassium sulphate were added. The flask was hoated unt11 the nolution beoame olear.

Both plorio aoid and 4,41-dichloro-2,3'-dinltrodiphenyl were analyzed by this method and aoourate results were seoured, as shown by the following table:

Compounds Mitrogen calculated Mtrogen Pound

Plorio ao1d

Picrio aold

4,41-diobloro-

2,31 -dinitrodipheny 1

4,4:-dionloro-

$2 ; 3$-dinl trodlpheny 2

$17.5 \%$

$8.9 \%$

$3.9 \%$
$17.02 \%$

$17.23 \%$

$8.7 \%$

$8.68 \%$

The method oan therefore be considered as beling dependable. 
CONCLUS ION 
The data oollected in this study indicated that two of the nitro-groups in 4,41-diohlorotrinitrodiphenyl are in the 2,3'-positions, as it has been shom that on further nitration of 4,4:-dichlero-2,3'-dinitrodiphenyl a nitro-oompound was formed whioh was identioel with 4,41-diohlorotrinitrodipheny 1 , melting at $164-165^{\circ}, 1$ s produced.

The 4,41-diohlorotrinitrodlphenyl, melting at 143-147 , bellered to have been an 18omer of 4,41d loblorotrinttrodiphenyl, melting at $164-165^{\circ}$, was shown to be mixture of di- and trinitro-compounds. By both weorystallization and further nitration of the product melting at $143-147^{\circ}$ a produot, which was 1dentioal with 4,41-diohlorotrinitrodiphenyl, and whioh melted at $164-165^{\circ}$, was obtained. In conclusion the eridence ladicated that only one trinttro-compound was produoed by direot nitration of 4,4'-dlohlorodipheny 1. Whether the reaction took place in steps or in one operation. 
BIBL IOGRAYHY 


\section{BIBLIOGRAPHY}

1. Rebernak, A., Mastex's thesis, Unirersity of Loularille.

2. We18a, J. M., and Downs, O.R., U.S. 1,322,983, Nov. 25. (0.A. 14, $287(1920))$.

3. Chamberi1n, Organio Chemistry, Blakloton, Ph11., p. 706.

4. Kamm, qualitative organic Chemistry, John W1 ley and sons, N. Y. p. 39.

5. Lellman, Dug., B. 1882, (15), 2837.

6. SoluItz, A. 207,174 .

7. Dennett, A. O. and Turner, E. E., J. Chem. Soo. 476 (1926).

8. U1Lman, 7 , and Bleleok1, J,

9. Sohmidt and sobultz, A. 207, 340. (bellstein-prager-Jaoobson, 5, 585 (1922)).

10. Hodgson, H. H. and Gorowara, F. O., J. Chem. soc. 1754 (1926).

11. Leferre, R. J. W. and Tumer, I. Z., J. Chem. Soo. 1759 (1926).

12. Gilman, H., Organic Bynthesis, John W1loy and sons, N. Y., VI, 57 .

13. Houben-Keyl, D10 Methoden der Organlsohen onemle, 2, p. 313 (Bellatein und Kurbatow, A. 176,44 (1875)). 
14. Ibld. Sohultz, A. $207,174$.

15. Oohn, A. J., quant. Ohem. Anal. 2, 1024

71915), scott, F., stand, Methods of chem. Analysia, 2, 341 (1922). 
AUTOBIOCRAPHY 


\section{AUTOBIOGRAPHY}

The author, H. Harrio Pawe, was born in Loulev1lle, Kentucky, January 26, 1908, Hs high sohool eduoation was reoelved at the Loulgvile Malo High Sohool, Loulavilie, Kentucky. He recelyed his under-graduate duoation at the Untreralty of Loularille, from whioh he graduated In June, 1930. He did his graduate work at the University of Loulerille from September 1930 to June 1932. 